\title{
Ala-geninthiocin, a new broad spectrum thiopeptide antibiotic, produced by a marine Streptomyces sp. ICN19
}

\author{
Appadurai Muthamil Iniyan ${ }^{1,2}$, Enge Sudarman ${ }^{3,4}$, Joachim Wink ${ }^{2,4}$, Rajaretinam Rajesh \\ Kannan ${ }^{5}$, Samuel Gnana Prakash Vincent ${ }^{1 *}$ \\ ${ }^{1}$ International Centre for Nanobiotechnology (ICN), Centre for Marine Science and Technology (CMST), Manonmaniam \\ Sundaranar University, Rajakkamangalam-629502, Kanyakumari District, Tamil Nadu, India; ${ }^{2}$ Microbial Strain Collection, \\ Helmholtz Centre for Infection Research GmbH (HZI), Inhoffenstrasse 7, 38124 Braunschweig, Germany; ${ }^{3}$ Department \\ Microbial Drugs, Helmholtz Centre for Infection Research GmbH (HZI), Inhoffenstrasse 7, 38124 Braunschweig, Germany; ${ }^{4}$ \\ German Centre for Infection Research Association (DZIF), Partner site Hannover-Braunschweig, Inhoffenstrasse 7, 38124 \\ Braunschweig, Germany; ${ }^{5}$ Molecular and Nanomedicine Research Unit, Centre for Nanoscience and Nanotechnology (CNSNT), \\ Sathyabama Institute of Science and Technology, Jeppiaar Nagar, Chennai-600119, TN, India. \\ *Correspondence: Prof. S.G.Prakash Vincent, International Centre for Nanobiotechnology (ICN), Centre for Marine Science and \\ Technology (CMST), Manonmaniam Sundaranar University, Rajakkamangalam-629502, Kanyakumari District, Tamil Nadu, \\ India. Tel.: +91 9442428248; fax: +914652 253078; E-mail: prakash.vincent@msuniv.ac.in
}

\begin{abstract}
Bioassay guided screening of antibacterial compounds from the cultured marine Streptomyces sp. ICN19 provided Ala-geninthiocin (1), along with its known analogs geninthiocin (2) and Valgeninthiocin (3) and the indolocarbazole staurosporine (4). The structure of 1 was determined on the basis of 1D and 2D NMR spectra and ESI-HRMS. The absolute configurations of the amino acid residues were determined by enantioselective GC-MS analysis. Compound 1 exhibited potent activity against Gram-positive bacteria including Staphylococcus aureus, Bacillus subtilis, Mycobacterium smegmatis and Micrococcus luteus as well as cytotoxicity against A549 human lung carcinoma cells with an $\mathrm{IC}_{50}$ value of $6 \mathrm{nM}$.
\end{abstract}

The desirable biological activity of thiopeptides has stimulated renewed interest in the search for new antibiotics to find promising lead molecules. New groups of actinomycetes from unexplored habitats are pursued as sources of novel bioactive secondary metabolites. It is perhaps not surprising that marine Streptomyces are proving to be such a valuable source of new bioactive compounds. ${ }^{1-3}$ As part of our continuing efforts to explore marine derived actinomycetes, a new thiopeptide antibiotic was isolated from Streptomyces strain ICN19 derived from a marine sediment. The bioassay-guided chromatographic purification yielded a new compound named as Ala-geninthiocin (1) besides the known geninthiocin (2), its analog Val-geninthiocin (3) and staurosporine (4) (Figure 1). Details of the extraction, purification, structure elucidation and biological activity are described herein.

Strong activity was found by bioassay screening against Staphylococcus aureus and Candida albicans in the acetone extract of Streptomyces sp. ICN19. After extracting the active metabolites with ethyl acetate and removing the lipids with $n$-heptane, the residue of the extract was fractionated using a reversed phased Medium-pressure liquid chromatography (MPLC) column with a methanol/water gradient. Of the 11 fractions collected, 3 fractions (fr. 4, 6 and 7) exhibited antibacterial activity, i.e. fr. 4 and 7 were active against $S$. aureus and fr. 6 was active against $C$. albicans. Fr. 4 was further purified using preparative RP-HPLC to give Ala- 
geninthiocin (1) along with geninthiocin (2). The preparative HPLC of fr. 7 yielded Valgeninthiocin (3). The analytical HPLC profile of MPLC fr. 6 showed a single peak of staurosporine (4). The compounds were separated as Val-geninthiocin with 7.62 min retention time (RT), Ala-geninthiocin with 8.34 min RT, geninthiocin with $9.02 \mathrm{~min}$ RT and staurosporine with $21.38 \mathrm{~min}$ RT. The identification of the three purified metabolites was confirmed by comparing their NMR data with those reported in the literature. ${ }^{4-6}$

The molecular formula $\mathrm{C}_{50} \mathrm{H}_{52} \mathrm{~N}_{15} \mathrm{O}_{15} \mathrm{~S}$ of Ala-geninthiocin (1) was determined by ESIHRMS analysis of the molecular ion clusters $[\mathrm{M}+\mathrm{H}]^{+}$at $\mathrm{m} / z 1134.3488$ and $[\mathrm{M}+\mathrm{Na}]^{+}$at $\mathrm{m} / z$ 1156.3297. The ${ }^{1} \mathrm{H}$ NMR spectrum of 1 in DMSO- $d_{6}$ displayed 6 methyls, 5 methylenes, 10 methines and 13 exchangeable protons. The ${ }^{13} \mathrm{C}$ and DEPT NMR spectra confirmed the number of 50 carbons and revealed the presence of ten carboxylic carbons between $\delta_{\mathrm{C}} 173.86$ and 158.39 , and five primary olefin carbons $\left(\delta_{\mathrm{C}} 111.3,105.8,105.7,103.8,103.8\right)$ as well as 18 quaternary olefin carbon signals. The ${ }^{1} \mathrm{H},{ }^{15} \mathrm{~N}$ HSQC spectrum showed ${ }^{1} J_{\mathrm{NH}}$ couplings of amide protons and a terminal $\mathrm{NH}_{2}$ group. The assignment of ${ }^{1} \mathrm{H}$ and ${ }^{13} \mathrm{C} \mathrm{NMR}$ data is presented in Table 1. Detailed analysis of the ${ }^{1} \mathrm{H},{ }^{1} \mathrm{H}$ COSY and TOCSY NMR spectra of 1 identified spin systems belonging to proteinogenic amino acids Ala and Thr, which were confirmed from the long range correlations in the ${ }^{1} \mathrm{H},{ }^{13} \mathrm{C}$ HMBC spectrum. They were also compatible with the amino acid analysis of the hydrolysis products. The presence of 2 oxazoles and 1 thiazole was shown by characteristic ${ }^{1} \mathrm{H}$ and ${ }^{13} \mathrm{C}$ chemical shifts at $\delta_{\mathrm{H}} 8.71,8.59$ and $8.49 \mathrm{ppm}\left(\delta_{\mathrm{C}} 142.8\right.$, 140.1 and 126.9) in conjunction with the ${ }^{1} \mathrm{H},{ }^{13} \mathrm{C}$ HMBC correlations to adjacent quaternary carbons (see Figure 2) a methyl signal at 2.62 and its long range correlations indicated the existence of a methyloxazole (Oxa-3) residue. ${ }^{4,7}$ The $\mathrm{Z}$ configuration of the methyl substituted double bond of Oxa-3 was established from an intraresidueal NOE between the methyl and NH protons. Furthermore, typical shifts, COSY and HMBC correlations identified the 2,3,6trisubstituted pyridine residue that has been found in other thiopeptides produced by Streptomyces. ${ }^{8,9}$

Sequential assignments were determined from the cross peaks in the ${ }^{1} \mathrm{H},{ }^{1} \mathrm{H}$ ROESY spectrum by the NOE between $\mathrm{H}_{\mathrm{N}}, \mathrm{H}_{\alpha}, \mathrm{H}_{\beta}$ in residue (i) to $\mathrm{H}_{\mathrm{N}}$ in residue (i+1). In combination with HMBC correlations the sequential assignment method provided the complete amino acid sequence of 1 which showed that Pyr-9 was attached to Thz-1 to form a cyclic peptide. Finally the Deala-10 chain was found to be attached to Pyr-9 through long range correlations from H-6 of Pyr and NH of Deala-10 to the carbonyl carbon at $161.2 \mathrm{ppm}$. The peptide structure of $\mathbf{1}$ is largely similar to geninthiocin. ${ }^{4}$ The only difference is the presence of an Ala residue instead of Deala at the C-terminal amide. The absolute stereochemistry of $\mathbf{1}$ was determined by enantioselective GC-MS analysis indicating the presence of L-Ala, L-Thr and L-Hyval. Furthermore, the absolute configuration of Hyval residue from geninthiocin was assigned from the GC-MS analysis to be L as well, which can be also inferred for Val-geninthiocin as reported in the literature.

Compounds 1 - 4 were evaluated for their antibiotic activities against a panel of human pathogenic bacteria, yeast and fungi and all exhibited strong antibiotic activity as shown in Table 2. Compounds 2, $\mathbf{3}$ and $\mathbf{4}$ were known to exhibit antimicrobial activity, ${ }^{5}$ and compound $\mathbf{4}$ also acts as an anticancer agent targeting protein kinases. ${ }^{10}$ Compound $\mathbf{1}$ showed inhibition of Staphylococcus aureus, Bacillus subtilis, Mycobacterium smegmatis, Micrococcus luteus, Chromobacterium violaceum, Candida albicans, Pichia anomala, and Mucor hiemalis. Compounds 1 and 2 inhibited $C$. violaceum but not compound 3. Similarly, compound 1 showed 
weak and compound $\mathbf{3}$ moderate activity against $C$. albicans while $\mathbf{2}$ was inactive. Thus, the antimicrobial activity of these analogs suggests that substitution of amino acids has little effect on their antimicrobial activity.

The thiopeptide antibiotics are inhibiting the growth of various drug-resistant pathogens,

Furthermore, these compounds showed potent cytotoxic activity against the tested cervix, including Methicillin-Resistant Staphylococcus aureus (MRSA) and VancomycinResistant Enterococci (VRE) by targeting the ribosome and thus inhibiting protein synthesis. ${ }^{11-13}$ Compound $\mathbf{1}$ showed potent antibacterial activity and weak antifungal activity. Comparatively, $\mathbf{3}$ showed better antifungal activity than its analogues. The antimicrobial activities of $\mathbf{2}$ and $\mathbf{3}$ described earlier ${ }^{5}$ are correlating with our findings. Further, $\mathbf{2}$ has been reported as an inducer of the tip A promoter in streptomycetes. ${ }^{4}$ breast, lung, prostate, epidermoid and ovarian human cancer cell lines. The $\mathrm{IC}_{50}$ values of the analog compounds $\mathbf{1}$ and $\mathbf{3}$ were moderately higher than those of the basic compound $\mathbf{2}$ (Table $3)$. However, compound $\mathbf{4}$ showed significantly higher cytotoxic activity. The anticancer activity of 4 is evidenced as broad-spectrum protein kinase inhibitor with mitochondrial caspase activation. $^{14,15}$ Cumulative research findings highlight the significant role of macrocyclic peptides in various cancer therapeutic modalities. Compound $\mathbf{1}$ showed cytotoxic $\mathrm{IC}_{50}$ values of $22 \mathrm{nM}$ against the mouse fibroblast cell line L929 and $6 \mathrm{nM}$ against the human lung carcinoma cell line A549. Overall, $\mathbf{1}$ showed a higher selectivity towards mammalian cell lines than $\mathbf{2}$ in the cytotoxicity assays. It has been reported previously that the thiopeptide antibiotic thiostrepton is active against human breast cancer by inhibiting the FoxM1 transcription factor involved in tumorigenesis in the MCF7 cell line, ${ }^{16}$ which is one of the possible modes of action of the thiopeptides described above.

In conclusion, along with the new thiopeptide Ala-geninthiocin (1), three bioactive compounds were isolated from the marine Streptomyces sp. ICN19. All have been assayed against a panel of human pathogenic bacteria, yeasts, and fungi for their antibiotic activity and against cervix, breast, lung, prostate, epidermoid, and ovarian human cancer cell lines and a murine fibrosarcoma cell line for anticancer activity. Macrocyclic peptides provide diverse functionality with high affinity and selectivity for target proteins, while maintaining adequate bioavailability for binding. The present findings indicate that the antibiotic and anticancer activity of the thiopeptides including the new thiopeptide Ala-geninthiocin (1), geninthiocin (2) and its analog Val-geninthiocin (3) may demand further preclinical evaluations for a future therapeutic use. The possible routes of their biosynthesis and preclinical safety are currently under investigation.

\section{MATERIALS AND METHODS}

\section{General experimental procedures}

Optical rotation was measured with a Perkin-Elmer 241 MC instrument, UV data recorded on a Shimadzu UV-Vis spectrophotometer UV-2450 using methanol (UVASOL, Merck). ${ }^{1} \mathrm{H}$ NMR, ${ }^{13} \mathrm{C}$ and ${ }^{15} \mathrm{~N}$ NMR spectra were recorded on a Bruker AVANCE DMX- $700\left({ }^{1} \mathrm{H} 700 \mathrm{MHz},{ }^{13} \mathrm{C}\right.$ $176 \mathrm{MHz}$ ) spectrometer. ESI-HRMS mass spectra were obtained with a Maxis ESI-TOF mass spectrometer (Bruker Daltonics) attached to an Agilent 1200 series HPLC system: column $100 \times 2.1 \mathrm{~mm}, \mathrm{C}_{18}$ XBridge TM, $3.5 \mu \mathrm{m}$ (Waters), solvent A: $5 \%$ acetonitrile in water, $5 \mathrm{mmol} \mathrm{L}^{-}$ ${ }^{1} \mathrm{NH} 4 \mathrm{Ac}, 0.04 \mathrm{ml} \mathrm{L}^{-1}$ acetic acid; solvent B: $95 \%$ acetonitrile in water, $5 \mathrm{mmol} \mathrm{L}^{-1}, 0.04 \mathrm{ml} \mathrm{L}^{-1}$ 
acetic acid, gradient $10 \% \mathrm{~B}$ increasing to $100 \% \mathrm{~B}$ in 30 min and maintaining $100 \% \mathrm{~B}$ for 10 min, flow rate $0.3 \mathrm{ml} \mathrm{min}{ }^{-1}$; UV detection 200-500 nm. Analytical RP-HPLC was carried out with an Agilent 1260 HPLC system equipped with a UV diode-array detector and a Corona Ultra detector (Dionex); column 125×2 mm, Nucleodur 5 $4 \mathrm{~m}$ C18 (Macherey Nagel), solvent A: $5 \%$ acetonitrile in water, 5 mmol L $\mathrm{NH}_{4} \mathrm{Ac}, 0.04 \mathrm{ml} \mathrm{L}^{-1}$ acetic acid, solvent $\mathrm{B}: 95 \%$ acetonitrile, 5 mmol L $\mathrm{NH}_{4} \mathrm{Ac}, 0.04 \mathrm{ml} \mathrm{L}^{-1}$ acetic acid, gradient from $10 \% \mathrm{~B}$ to $100 \% \mathrm{~B}$ in $30 \mathrm{~min}, 10 \mathrm{~min}$

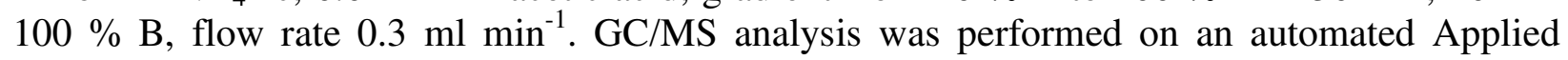
Biosystems ABI-420-A amino acid analyser.

\section{Producer strain}

The strain Streptomyces sp. ICN19 was isolated from subtidal marine sediment collected at two feet depth at Chinnamuttam coast of Kanyakumari, India, and isolated using standard dilutionplating with the modified Gause's inorganic agar media ${ }^{17}$ containing $20 \mathrm{~g}$ soluble starch, $1 \mathrm{~g}$ $\mathrm{KNO}_{3}, 0.5 \mathrm{~g} \mathrm{~K}_{2} \mathrm{HPO}_{4}, 0.5 \mathrm{~g} \mathrm{MgSO}_{4} \cdot 7 \mathrm{H}_{2} \mathrm{O}, 0.01 \mathrm{~g} \mathrm{FeSO}_{4} \cdot 7 \mathrm{H}_{2} \mathrm{O}, 18 \mathrm{~g}$ agar in $1 \mathrm{~L}$ of $50 \%$ sea water (pH 7.2-7.4). A pure culture was maintained in a glycerol suspension $(20 \%, \mathrm{w} / \mathrm{v})$ at -20 ${ }^{\circ} \mathrm{C}$. 16S rRNA gene sequencing was carried out and the aligned sequence was identified against closely related sequences of representative Streptomyces sp. retrieved from the GenBank and EzTaxon databases. The sequence was deposited in GenBank with the accession number KU738607.

\section{Screening, extraction and Isolation}

GYM broth medium containing glucose $4 \mathrm{~g}$, yeast extract $4 \mathrm{~g}$, malt extract $10 \mathrm{~g}, \mathrm{CaCO}_{3} 2 \mathrm{~g}$ and distilled water $1 \mathrm{~L}$ adjusted at $\mathrm{pH} 7.2$ using $\mathrm{KOH}$ was inoculated with a $1 \mathrm{~cm}^{2}$ agar plug of a well sporulated mycelium from Streptomyces sp. ICN19 and incubated in a shaker at $30{ }^{\circ} \mathrm{C}$ up to seven days. After 7 days $5 \%$ by volume of this inoculum was transferred into $10 \mathrm{~L}$ shake flasks (100 x $250 \mathrm{ml}$ flask with $100 \mathrm{ml}$ broth) of medium HZI 5254 containing glucose $15 \mathrm{~g}$, soymeal $15 \mathrm{~g}$, corn steep $5 \mathrm{~g}, \mathrm{CaCO}_{3} 2 \mathrm{~g}, \mathrm{NaCl} 5 \mathrm{~g}$ and distilled water $1 \mathrm{~L}$ at $\mathrm{pH} 7.0$ and incubated in a shaker at $30{ }^{\circ} \mathrm{C}$ up to five days. The production broth was harvested by centrifuging at 7,000 rpm. Mycelial biomass and cell free supernatant were collected separately. The mycelial cake was extracted three times with acetone $(900 \mathrm{ml})$. After filtration and evaporation, the residual water phase was partitioned with ethyl acetate six times and dried in vacuo. The residue (1.94 g) of the ethyl acetate extract was further dissolved in methanol $(+10 \%$ water $)$ and extracted six times against $n$-heptane to remove the liphophilic components. The methanol phase was dried to afford $996 \mathrm{mg}$ crude extract. The extract was separated by preparative RP-MPLC chromatography [column $480 \times 30 \mathrm{~mm}$, ODS AQ, $120 \AA$, $16 \mu \mathrm{m}$ (Kronlab); solvent A: water/methanol 1/1, solvent B: methanol, gradient: $20 \% \mathrm{~B}$ isocratic $4 \mathrm{~min}$, from $20 \% \mathrm{~B}$ to $80 \%$ $\mathrm{B}$ in $260 \mathrm{~min}$, from $80 \% \mathrm{~B}$ to $100 \% \mathrm{~B}$ in $30 \mathrm{~min}$; flow rate $30 \mathrm{ml} \mathrm{min}{ }^{-1}$, UV detection $210 \mathrm{~nm}$ ]. Totally 11 fractions were collected and tested against $S$. aureus and C. albicans. The analytical HPLC profile of MPLC Fr. 6 containing $41 \mathrm{mg}$ of staurosporine (4) was found to be pure and was active against $C$. albicans. Fr. $4(285 \mathrm{mg})$ with strong activity against $S$. aureus was separated by preparative RP-HPLC [column: $250 \times 21.2 \mathrm{~mm}$, Nucleodur 100-10 $\mathrm{C}_{18}$ (MachereyNagel); solvent A: water, solvent B: acetonitrile, gradient from $30 \%$ B to $60 \%$ B in 60 min, 10

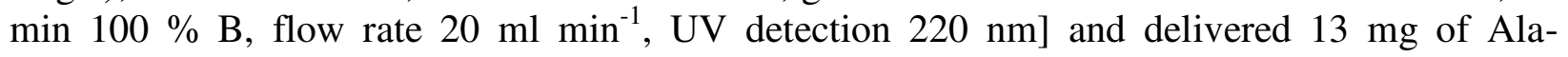
geninthiocin (1) and $73 \mathrm{mg}$ of geninthiocin (2) as the main compound. Fr. 7 (23 mg) was purified using $35 \% \mathrm{~B}$ to $55 \% \mathrm{~B}$ in $60 \mathrm{~min}$ and $100 \% \mathrm{~B}$ for $10 \mathrm{~min}$ to yield $2.6 \mathrm{mg}$ of Val-geninthiocin (3). 
181 Sample was hydrolyzed using $4 \mathrm{~N}$ TFA at $110^{\circ} \mathrm{C}$ for $24 \mathrm{~h}$. After drying, the resulting free amino 182 acids were derivatized with $4 \mathrm{~N} \mathrm{HCl} /$ propan-2-ol $\left(1 \mathrm{~h}, 110^{\circ} \mathrm{C}\right)$ and, after removal of reagents, the amino acid isopropyl esters were then acylated with pentafluoropropionic acid anhydride in $184 \mathrm{CH}_{2} \mathrm{Cl}_{2}\left(150{ }^{\circ} \mathrm{C}, 12 \mathrm{~min}\right)$. Excess reagents were again removed and the amino acid derivates analyzed on a Chirasilval column $(50 \mathrm{~m})$ connected to a GCQ ion trap mass spectrometer. The constituent amino acids were identified by their characteristic mass spectra and their enantiomerity was determined by comparison to standard D and L amino acids. D-Ala 10.42, LAla 10.86, D-Thr 11.93, L-Thr 12.13, D-Hyval 12.35 and L-Hyval 12.47 min were used as commercial reference standard.

Ala-geninthiocin (1): $\mathrm{C}_{50} \mathrm{H}_{51} \mathrm{~N}_{15} \mathrm{O}_{15} \mathrm{~S}$, white amorphous solid; $[\alpha]_{\mathrm{D}}{ }^{20}=+92.8\left(\right.$ c $\left.1.38, \mathrm{CH}_{3} \mathrm{OH}\right)$; $\mathrm{UV} / \mathrm{Vis}\left(\mathrm{CH}_{3} \mathrm{OH}\right): \lambda_{\max }\left(\log \varepsilon_{\max }\right)=237 \mathrm{~nm}(4.67)$; NMR spectroscopic data $\left({ }^{1} \mathrm{H}: 700 \mathrm{MHz},{ }^{13} \mathrm{C}\right.$ : $176 \mathrm{MHz}, \mathrm{CDCl}_{3}$ ) Table 1; ESI-HRMS: $\mathrm{C}_{50} \mathrm{H}_{52} \mathrm{~N}_{15} \mathrm{O}_{15} \mathrm{~S}[\mathrm{M}+\mathrm{H}]^{+} \mathrm{m} / z$ calcd 1134.3483 , found 1134.3488; $\mathrm{C}_{50} \mathrm{H}_{51} \mathrm{~N}_{15} \mathrm{O}_{15} \mathrm{SNa}[\mathrm{M}+\mathrm{Na}]^{+} \mathrm{m} / z$ calcd 1156.3302, found 1156.3297 . 96-well microtiter plates with EBS medium $(0.5 \%$ peptone, $0.5 \%$ glucose, $0.1 \%$ meat extract, $0.1 \%$ yeast extract, $50 \mathrm{mM}$ HEPES for bacteria and MYC medium for yeast and fungi respectively. Twenty microliter aliquots $\left(150 \mu \mathrm{g} \mathrm{ml}^{-1}\right.$ from $1 \mathrm{mg} \mathrm{ml}^{-1}$ concentration) of compounds were tested against four different Gram-positive (Staphylococcus aureus DSM 346, Bacillus subtilis DSM 10, Mycobacterium smegmatis DSM 43756, Micrococcus luteus DSM 1790) and three Gram-negative bacteria (Chromobacterium violaceum DSM 30191, Pseudomonas aeruginosa DSM 1128, Escherichia coli DSM 1116, Escherichia coli TolC), two yeasts (Candida albicans DSM 1386, Pichia anomala DSM 6766) and a fungal strain (Mucor hiemalis DSM 63298). Negative control wells were left blank. Compounds were dissolved in methanol. Cell density was adjusted to about $5 \times 10^{6} \mathrm{ml}^{-1}$.

Cytotoxicity assay: In vitro cytotoxicity $\left(\mathrm{IC}_{50}\right)$ was determined against seven cancer cell lines. A $60 \mu \mathrm{l}$ amount of serial dilutions from an initial stock of $1 \mathrm{mg} \mathrm{ml}^{-1}$ in Methanol of the test compounds was added to $120 \mu \mathrm{l}$ aliquots of a cell suspension $\left(50000 \mathrm{ml}^{-1}\right)$ in 96-well microplates. After 5 days of incubation, an MTT (3-(4,5-dimethylthiazol-2-yl)-2,5diphenyltetrazolium bromide) assay was performed, and the absorbance measured at $590 \mathrm{~nm}$ using an ELISA plate reader (Victor). The concentration, at which the growth of cells was inhibited to $50 \%$ of the control $\left(\mathrm{IC}_{50}\right)$, was obtained from the dose-response curves. The negative control was methanol.

\section{ACKNOWLEDGEMENTS}

The support of the Department of Science and Technology, Science and Engineering Research Board (DST-SERB), Govt. of India [F.No. SR/SO/HS-104/2012] to SGPV is gratefully acknowledged. The European Molecular Biology Organization (EMBO) is gratefully acknowledged for the Short term fellowship grant to A.M. Iniyan [ASTF No. 90 - 2016]. We thank Manfred Nimtz for the GC-MS analysis of amino acids. We thank Christel Kakosche, Romy Schade and Wera Collisi for their excellent technical assistance. 
The authors declare no competing financial interest.

References

1. Raju R, Andrew M P, Zeinab K, Bernhardt PV, Capon RJ. Heronamycin A: a new benzothiazine ansamycin from an Australian marine-derived Streptomyces sp [J]. Tetrahedr Lett. 2012;53:1063-5.

2. Mullowney MW, et al. Diazaquinomycins E-G, novel diaza- anthracene analogs from a marine derived Streptomyces sp. Mar Drugs. 2014;12:3574-86.

3. Vicente J, et al. Monacyclinones, new angucyclinone metabolites isolated from Streptomyces sp. M7-15 associated with the Puerto Rican sponge Scopalina ruetzleri. Mar Drugs. 2015;13:4682-700.

4. Yun BS, Hidaka T, Furihata K, Seto H. Microbial metabolites with tipA promoter inducing activity. II. Geninthiocin, a novel thiopeptide produced by Streptomyces sp. DD84. J Antibiot. 1994;47:969-75.

5. Sajid I, Shaaban KA, Frauendorf H, Hasnain S, Laatsch HZ. Val- Geninthiocin: Structure elucidation and MSn fragmentation of thiopeptide antibiotics produced by Streptomyces sp. RSF18. Z Naturforsch. 2008;B63:1223-30.

6. Schupp P, Proksch P, Wray V. Further new staurosporine derivatives from the ascidian Eudistoma toealensis and its predatory flatworm Pseudoceros sp. J Nat Prod 2002;65:295-8.

7. Yun BS, Seto H. Promoinducin, a novel thiopeptide produced by Streptomyces sp. SF2741. Biosci Biotech Biochem. 1995;59:876-80.

8. Abe H, Kushida K, Shiobara Y, Kodama M. The sutructures of sulfomycin I and berninamycin A. Tetrahedr Lett. 1988;29:1401-4.

9. Bowers AA, Waslch CT. Genetic interception and structural characterization of thiopeptide cyclization precursors from Bacillus cereus. J Am Chem Soc. 2010;132:12182-4.

10. Gescher A. Analogs of Staurosporine: Potential anticancer drugs? Gen Pharmac. 1998;31:721-8.

11. Porse BT, Leviev I, Mankin A, Garrett RA. The antibiotic thiostrepton inhibits a functional transition within protein L11 at the ribosomal GTPase centre. J Mol Biol. 1998;276:391-404.

12. Harms JM, et al. Translational regulation via L11: molecular switches on the ribosome turned on and off by thiostrepton and micrococcin. Mol Cell 2008;30:26-38.

13. Zhang Q, Liu W. Biosynthesis of thiopeptide antibiotics and their pathway engineering. Nat Prod Rep. 2013;30:218-26.

14. Tamaoki T. et al. Staurosporine, a potent inhibitor of phospholipid/Ca kinase. Biochem Biophys Res Commun. 1986;135:397-402.

15. Bertrand R, Solary E, O' Connor P, Kohn KW, Pommier Y. Induction of a common pathway of apoptosis by staurosporine. Exp Cell Res. 1994;211:314-21.

16. Hegde NS, Sanders DA, Rodriguez R, Balasubramanian S. The transcription factor FOXM1 is a cellular target of the natural product thiostrepton. Nat Chem. 2011;3:725-31.

17. Gause GF, Preobrazhenskaya TP, Sveshnikova GV, Terekhova LP, Maksimova TS. A guide for determination of actinomycetes. Moscow: Nauka (in Russian) (1983). 
268 Supplementary Information is linked to the online version of the paper at

269 www.nature.com/nature.

270

271

272

273

274 


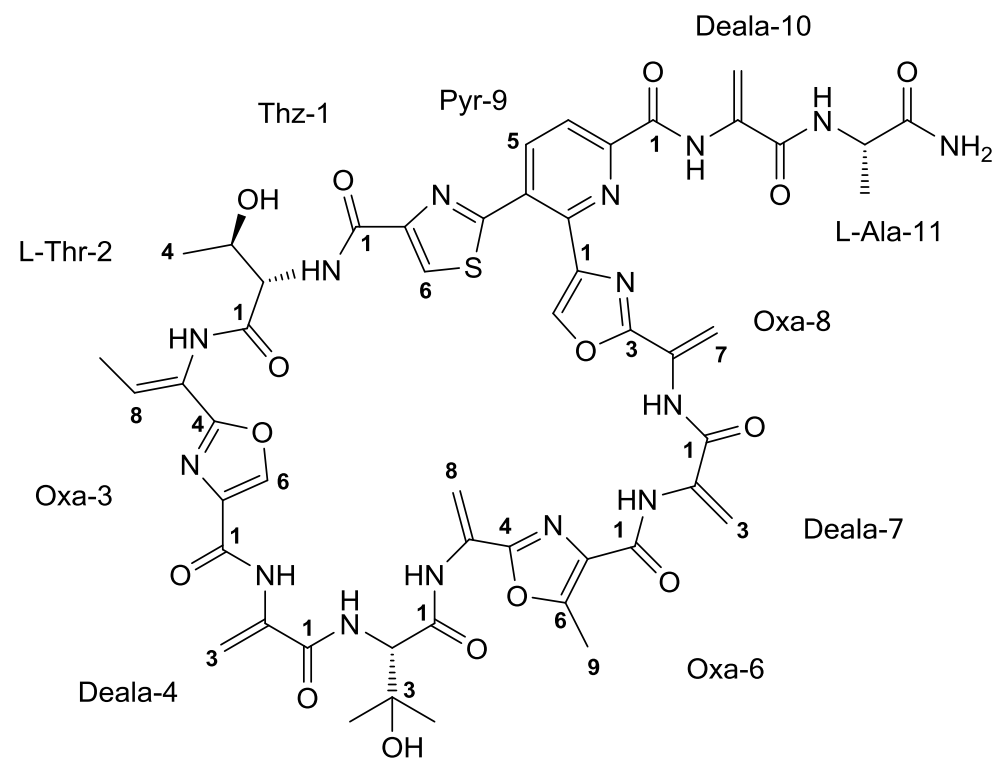

L-Hyval-5

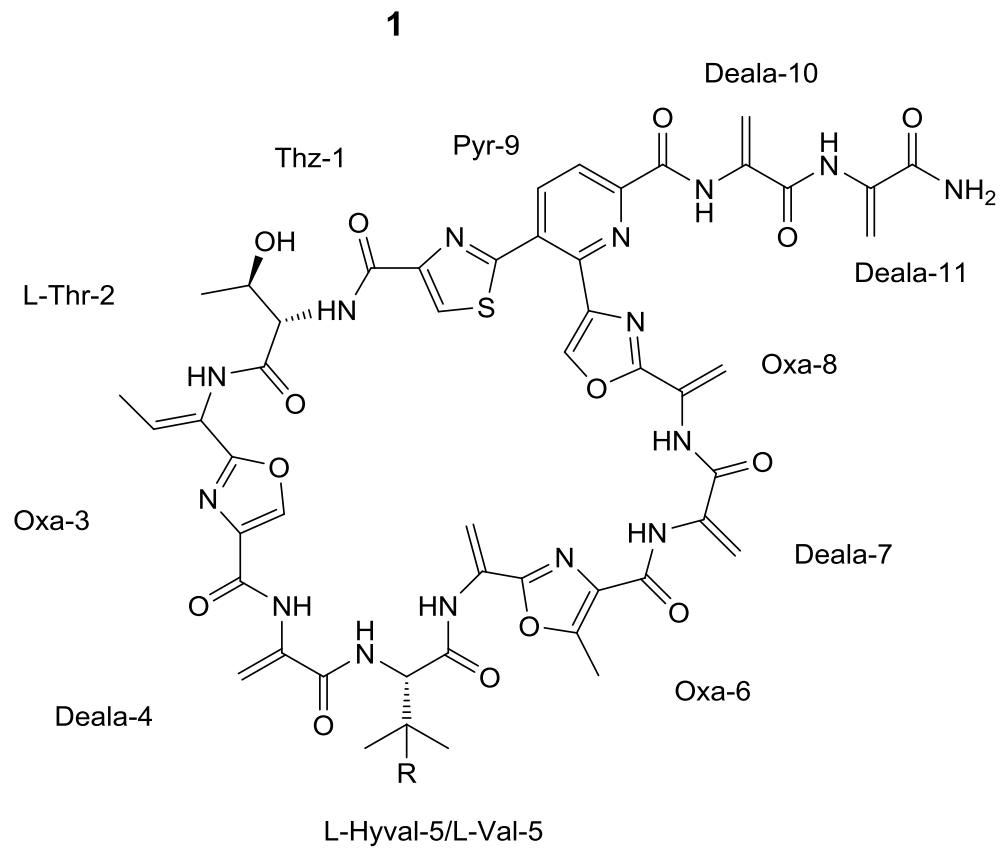

Figure 1. Structures of isolated compounds (1 - 3) from Streptomyces sp. ICN19. 


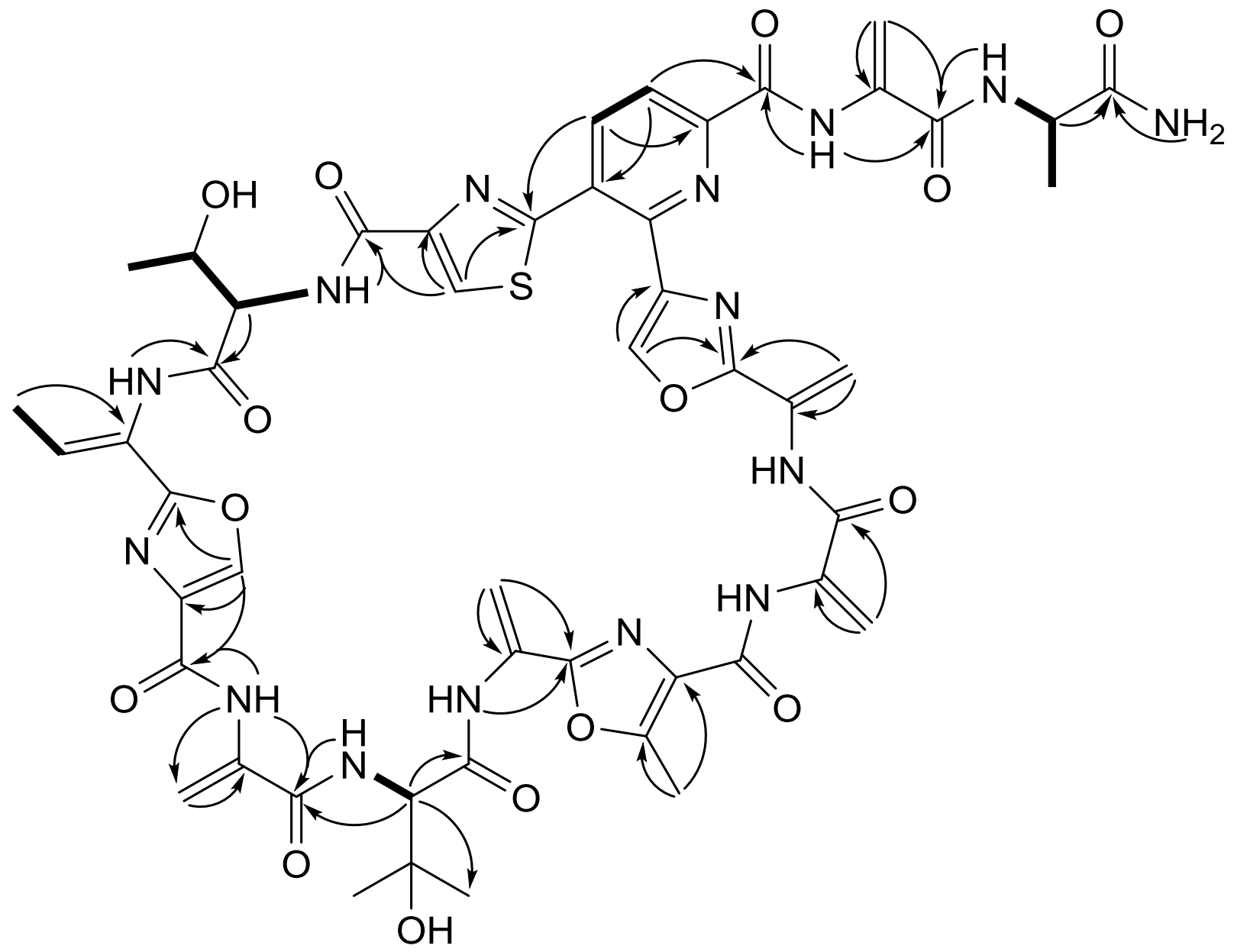

Figure 2. Selected ${ }^{1} \mathrm{H},{ }^{1} \mathrm{H}$ COSY (bold bonds) and ${ }^{1} \mathrm{H},{ }^{13} \mathrm{C} \mathrm{HMBC}$ (arrows) correlations of Alageninthiocin (1). 
288 Table 1. ${ }^{1} \mathrm{H}$ and ${ }^{13} \mathrm{C}$ NMR data of Ala-geninthiocin (1) in DMSO- $d_{6}\left({ }^{1} \mathrm{H} 700.4 \mathrm{MHz},{ }^{13} \mathrm{C} 176.1\right.$ $289 \mathrm{MHz})$.

\begin{tabular}{|c|c|c|c|c|}
\hline unit & Pos. & $\delta_{\mathrm{H}}$, mult $(J$ in $\mathrm{Hz})$ & $\delta_{\mathrm{C}}$ & $\begin{array}{l}\text { Sequential } \\
\text { NOEs }^{a}\end{array}$ \\
\hline \multirow[t]{4}{*}{ Thz-1 } & 1 & - & $159.9, \mathrm{C}$ & \\
\hline & 2 & - & $149.4^{c}, \mathrm{C}$ & \\
\hline & 4 & - & 163.1, C & \\
\hline & 6 & $8.49, \mathrm{~s}$ & $126.9, \mathrm{CH}$ & Thr-2-NH \\
\hline \multirow[t]{6}{*}{ Thr-2 } & $\mathrm{NH}$ & $8.02, \mathrm{~d}(8.7)$ & - & Oxa-3-NH \\
\hline & 1 & - & $168.8, \mathrm{C}$ & \\
\hline & 2 & $\begin{array}{l}4.61, \mathrm{dd} \\
(8.7,3.1)\end{array}$ & $57.8, \mathrm{CH}$ & Oxa-3-NH \\
\hline & 3 & $4.29, \mathrm{~m}$ & $67.3, \mathrm{CH}$ & Oxa-3-NH \\
\hline & 4 & $1.15, \mathrm{~d}(6.1)$ & $20.5, \mathrm{CH}_{3}$ & \\
\hline & $\mathrm{OH}$ & $5.02, \mathrm{~d}(5.4)$ & - & \\
\hline \multirow[t]{8}{*}{ Oxa-3 } & $\mathrm{NH}$ & 9.63, br. s & - & \\
\hline & 1 & - & $158.4, \mathrm{C}$ & \\
\hline & 2 & - & 136.1, C & \\
\hline & 4 & & 159.4, C & \\
\hline & 6 & $8.72, \mathrm{~s}$ & $142.8, \mathrm{CH}$ & Deala-4-NH \\
\hline & 7 & - & 123.1, C & \\
\hline & 8 & $6.55, \mathrm{q}(7.2)$ & 129.6, CH & \\
\hline & 9 & $1.75, \mathrm{~d}(7.2)$ & $13.8, \mathrm{CH}_{3}$ & \\
\hline \multirow[t]{5}{*}{ Deala-4 } & $\mathrm{NH}$ & $9.39^{b}$, br. s & - & Hyval-5-NH \\
\hline & 1 & - & 163.7, C & \\
\hline & 2 & - & 133.4, C & \\
\hline & $3 a$ & $5.88, \mathrm{~s}$ & 103.7, $\mathrm{CH}_{2}$ & Hyval-5-NH \\
\hline & $3 b$ & $6.46, \mathrm{~s}$ & & Hyval-5-NH \\
\hline \multirow[t]{6}{*}{ Hyval-5 } & NH & $8.27, \mathrm{~d}(6.8)$ & - & Oxa-6-NH \\
\hline & 1 & - & $169.4, \mathrm{C}$ & \\
\hline & 2 & $4.63, \mathrm{~d}(6.8)$ & $61.8, \mathrm{CH}$ & \\
\hline & 3 & - & 71.0, C & \\
\hline & 4 & $1.23, \mathrm{~s}$ & 27.3, $\mathrm{CH}_{3}$ & \\
\hline & 5 & $1.21, \mathrm{~s}$ & $26.2, \mathrm{CH}_{3}$ & Oxa-6-NH \\
\hline \multirow[t]{9}{*}{ Oxa-6 } & $\mathrm{NH}$ & 9.65 , br. s & - & \\
\hline & 1 & - & $159.5, \mathrm{C}$ & \\
\hline & 2 & - & $129.2, \mathrm{C}$ & \\
\hline & 4 & - & 155.2, C & \\
\hline & 6 & - & 154.5, C & \\
\hline & 7 & - & 128.6, C & \\
\hline & $8 \mathrm{a}$ & $5.66, \mathrm{~s}$ & 105.7, $\mathrm{CH}_{2}$ & \\
\hline & $8 b$ & $6.11, \mathrm{~s}$ & & \\
\hline & 9 & $2.62, \mathrm{~s}$ & $11.6, \mathrm{CH}_{3}$ & \\
\hline \multirow[t]{3}{*}{ Deala-7 } & $\mathrm{NH}$ & $9.39^{b}$ & - & \\
\hline & 1 & - & 162.7, C & \\
\hline & 2 & - & $133.8, \mathrm{C}$ & \\
\hline
\end{tabular}




\begin{tabular}{|c|c|c|c|c|}
\hline & $3 a$ & $5.77 \mathrm{~s}$ & 105.8 & Oxa-8-NH \\
\hline & $3 b$ & $6.36, \mathrm{~s}$ & & Oxa-8-NH \\
\hline \multirow[t]{6}{*}{ Oxa-8 } & $\mathrm{NH}$ & 9.82, br. s & - & \\
\hline & 1 & - & $139.1, \mathrm{C}$ & \\
\hline & 3 & - & $158.3, \mathrm{C}$ & \\
\hline & 5 & $8.59, \mathrm{~s}$ & $140.1, \mathrm{CH}$ & \\
\hline & 6 & & $129.2, \mathrm{C}$ & \\
\hline & 7 & $5.71, \mathrm{~s}$ & $111.3, \mathrm{CH}_{2}$ & \\
\hline \multirow[t]{5}{*}{ Pyr-9 } & 1 & - & $161.2, \mathrm{C}$ & \\
\hline & 2 & - & $146.8, \mathrm{C}$ & \\
\hline & 4 & - & $149.4^{c}, \mathrm{C}$ & \\
\hline & 5 & $8.53, \mathrm{~d}(8.0)$ & $140.9, \mathrm{CH}$ & \\
\hline & 6 & $8.25, \mathrm{~d}(8.0)$ & $121.4, \mathrm{CH}$ & \\
\hline \multirow[t]{5}{*}{ Deala-10 } & $\mathrm{NH}$ & 10.61, br. s & - & Ala-11-NH \\
\hline & 1 & - & $162.9, \mathrm{C}$ & \\
\hline & 2 & - & $133.8, \mathrm{C}$ & \\
\hline & $3 a$ & $5.91, \mathrm{~s}$ & $103.8, \mathrm{CH}_{2}$ & \\
\hline & $3 b$ & $6.50, \mathrm{~s}$ & & \\
\hline \multirow[t]{6}{*}{ Ala-11 } & NH & 8.63, br. d (7.3) & & \\
\hline & 1 & - & $173.9, \mathrm{C}$ & \\
\hline & 2 & $4.34, \mathrm{dq}(7.3,7.2)$ & $49.0, \mathrm{CH}$ & \\
\hline & 3 & $1.32, \mathrm{~d}(7.2)$ & $17.7, \mathrm{CH}_{3}$ & \\
\hline & $\mathrm{NH}_{2}$ & $7.39, \mathrm{~s}$ & & \\
\hline & & $7.01 . \mathrm{s}$ & & \\
\hline
\end{tabular}

$290 \quad{ }^{\mathrm{a}}$ From the ROESY spectrum. ${ }^{b}$ Overlap of ${ }^{1} \mathrm{H}$ signals; ${ }^{c}$ Overlap of ${ }^{13} \mathrm{C}$ signals. 
Table 2. Antibacterial and antifungal activities of compounds $\mathbf{1}$ - $\mathbf{4}$.

\begin{tabular}{|c|c|c|c|c|}
\hline & \multicolumn{4}{|c|}{$\mathrm{MIC}\left(\mu \mathrm{g} \mathrm{ml}^{-1}\right)$} \\
\hline & 1 & 2 & 3 & 4 \\
\hline \multicolumn{5}{|l|}{ Gram Positive } \\
\hline Staphylococcus aureus DSM346 & 15 & 4 & 8 & 19 \\
\hline Bacillus subtilis DSM10 & 4 & 0.2 & 8 & 15 \\
\hline $\begin{array}{l}\text { Mycobacterium smegmatis } \\
\text { DSM43756 }\end{array}$ & 10 & 2 & 16 & 15 \\
\hline Micrococcus luteus DSM1790 & 1 & 0.2 & 2 & 5 \\
\hline \multicolumn{5}{|l|}{ Gram Negative } \\
\hline $\begin{array}{l}\text { Pseudomonas aureginosa } \\
\text { DSM1128 }\end{array}$ & - & - & - & - \\
\hline $\begin{array}{l}\text { Chromobacterium violaceum } \\
\text { DSM30191 }\end{array}$ & 19 & 19 & - & - \\
\hline E. coli DSM1116 & - & - & - & - \\
\hline E. coli TolC & - & - & - & 8 \\
\hline \multicolumn{5}{|l|}{ Yeasts } \\
\hline Candida albicans DSM1386 & 150 & - & 33 & 1 \\
\hline Pichia anomala DSM6766 & 75 & 150 & 66 & 1 \\
\hline \multicolumn{5}{|l|}{ Fungi } \\
\hline Mucor hiemalis DSM63298 & 75 & 38 & 16 & 1 \\
\hline
\end{tabular}

297 Note: - = no activity observed up to $150 \mu \mathrm{g} \mathrm{ml}^{-1}$.

298

299

300

301

\begin{tabular}{lcccc}
\hline & \multicolumn{3}{c}{ IC $_{\mathbf{5 0}}$ (nM) } \\
Cell line & $\mathbf{1}$ & $\mathbf{2}$ & $\mathbf{3}$ & $\mathbf{4}$ \\
\hline L929 murine fibrosarcoma & 22 & 25 & 8 & 0.26 \\
KB3.1 human cervix carcinoma & 22 & 247 & 53 & 9 \\
MCF-7 human breast carcinoma & 32 & 821 & 108 & 39 \\
A549 human lung carcinoma & 6 & 24 & 12 & 1 \\
PC-3 human caucasian prostate adenocarcinoma & 33 & 194 & 22 & 10 \\
A431 human epidermoid carcinoma & 29 & 141 & 42 & 2 \\
SKOV-3 human ovarian carcinoma & 33 & 194 & 29 & 8 \\
\hline
\end{tabular}

Table 3. Cytotoxic activities of compounds 1 - 4 